\title{
Pengembangan Modul Deteksi Risiko Perdarahan Pada Kehamilan Efektif Meningkatkan Pengetahuan Ibu Hamil
}

\author{
Development of Bleeding Risk Detection's Module in Pregnancy \\ Effectively Increasing Knowledge of Pregnant Women
}

\author{
Vinny Alvionita1, Esther Sanda Manapa², Mardiana Ahmad ${ }^{3}$, Werna Nontji ${ }^{4}$, \\ Deviana Soraya Riu ${ }^{5}$, Andi Nilawaty Usman ${ }^{6}$ \\ ${ }^{1}$ Program Studi Ilmu Kebidanan Sekolah Pascasarjana, Universitas Hasanuddin \\ ${ }^{2}$ Sekolah Pascasarjana, Universitas Hasanuddin, Makassar \\ ${ }^{3}$ Departemen Obsetri dan Ginekologi Fakultas Kedokteran, Universitas \\ Hasanuddin, Makassar \\ ${ }^{4,5,6}$ Program Studi Ilmu Kebidanan, Universitas Hasanuddin, Makassar \\ ${ }^{1}$ Email: vinnyalvionita@pasca.unhas.ac.id
}

\begin{abstract}
ABSTRAK
Tujuan peneltian ini adalah menghasilkan modul deteksi risiko perdarahan pada kehamilan untuk meningkatkan pengetahuan ibu hamil. Metode penelitian menggunakan langkah-langkah pengembangan model Borg and Gall. Desain penelitian menggunakan quasi eksperiment dengan rancangan pre post test design. Teknik pengambilan sampel adalah purposive sampling dengan jumlah sampel 30 ibu hamil. Partisipan penelitian adalah dua ahli media, dua ahli materi dan $10 \mathrm{ibu}$ hamil. Penelitian dilakukan di Wilayah Puskesmas Tajuncu Kabupaten Soppeng pada Oktober 2019 - Februari 2020. Efektifitas modul diukur selang waktu 1 minggu sebelum dan setelah modul diberikan. Data dianalisis dan diuji statistik dengan uji Wilcoxon.Hasil penelitian menunjukkan bahwa validasi modul deteksi risiko perdarahan pada kehamilan dinilai sangat baik dan didapatkan nilai rata-rata pengetahuan pre test sebesar $60 \%$ meningkat menjadi $85 \%$ setelah diberikan modul deteksi risiko perdarahan pada kehamilan dengan hasil uji Wilcoxon $p$ - value $0,000<0,05$. Hal tersebut membuktikan bahwa modul yang dikembangkan efektif meningkatkan pengetahuan ibu hamil untuk mendeteksi perdarahan pada kehamilan.
\end{abstract}

Kata kunci: Modul Deteksi Risiko Perdarahan, kehamilan, pengembangan, Borg and Gall..

\section{ABSTRACT}

The purpose of this research was to produce a risk detection module for bleeding in pregnancy to increase the knowledge of pregnant women. The research method used steps in developing the Borg and Gall model. The research design used quasi experiment with pre-post test design. The sampling technique was purposive sampling with a sample of 30 pregnant women. The study participants were two media experts, two material experts and 10 pregnant women. The study was conducted in the Tajuncu Community Health Center in Soppeng Regency in October 2019-February 2020. The effectiveness of the module was measured at intervals of one week before and after the module was given. Data were analyzed and statistically tested by the Wilcoxon test.The results showed that the validation of the bleeding risk detection module in pregnancy was considered very good and obtained an average value of pre-test knowledge by $60 \%$ increased to $85 \%$ after being given a bleeding risk detection module in pregnancy with the Wilcoxon test result p-value 0,000 $<0.05$. This proves that the module developed is effective in increasing the knowledge of pregnant women to detect bleeding in pregnancy.

Keywords: Bleeding Risk Detection Module, pregnancy, development, Borg and Gall.

PENDAHULUAN

Deteksi dini kehamilan dengan penilaian faktor risiko adalah suatu upaya menemukan ibu hamil yang mengalami komplikasi (Kemenkes RI, 2010). Jika faktor risiko tidak dapat 
diidentifikasi maka akan berakibat pada keterlambatan menentukan diagnosa sehingga berujung pada komplikasi yang terlambat ditangani (Geller et al., 2018). Indonesia merupakan urutan kedua dengan angka kematian ibu tertinggi di Asia Tenggara setelah Laos yaitu 305 per 100.000 kelahiran dan penyebab terbesar adalah perdarahan dengan presentase 30,1\% (Achadi, 2019). Pada tahun 2017 Sulawesi Selatan masuk dalam 10 besar daftar wilayah provinsi dengan angka kematian ibu dan bayi tertinggi, penyebab kematian ibu tersebut paling tinggi karena perdarahan dengan presentase $34,7 \%$. Oleh karena itu menurut Kepala Dinkes Sulawesi Selatan, perlu dilakukan deteksi dini dan penanganan yang tepat untuk masalah tersebut

(https://makassar.sindonews.com).

Perdarahan pada kehamilan berdampak pada perdarahan hebat yang terjadi secara tiba-tiba mengakibatkan kehilangan banyak darah sehingga dapat meningkatkan angka kesakitan dan kematian ibu dan bayi (Geller et al., 2018).

Menganalisis hal di atas, memberikan gambaran adanya masalah serta perlunya penanganan khusus. Perdarahan kehamilan sebenarnya dapat dicegah apabila dilakukan deteksi awal pada wanita yang berisiko (Senkoro et al., 2017), ditunjang dengan memadainya informasi yang didapatkan ibu hamil saat pemeriksaan kesehatan (Anggraini et al., 2018). Mewujudkan manajemen deteksi risiko dini pada ibu hamil diperlukan perencanaan, pembinaan dan pemantauan kegiatan yang intensif (Widiastuti et al., 2014). Manajemen deteksi risiko pada ibu hamil dapat dilakukan oleh tenaga kesehatan dan masyarakat yaitu dengan melakukan penilaian faktor risiko. Apabila faktor risiko telah dikenali maka ibu hamil dan masyarakat dapat mempersiapkan dirinya untuk menghadapi kegawatdaruratan maternal dan neonatal (Sikder et al., 2014). Oleh karena itu, wanita hamil yang mengetahui tanda bahaya dalam kehamilannya akan berusaha mencari pertolongan tenaga kesehatan (Sasnitiari, 2017).

Berdasarkan data di lapangan, kemampuan masyarakat Kabupaten Soppeng dalam mendeteksi risiko masih rendah yaitu berada di angka 44,81\% dari target sebesar $80 \%$ (Dinkes Soppeng, 2018). Hasil studi pendahuluan yang dilakukan mendapati hasil, bahwa pengetahuan masyarakat kabupaten Soppeng dalam mendeteksi risiko 
perdarahan dalam kehamilan masih rendah yaitu sebesar $52,4 \%$ pada ibu hamil dan 54,5 \% pada wanita tidak hamil.

Melihat fenomena di atas maka diperlukan media penyampaian pesan dari bidan sebagai sumber informasi kepada ibu hamil. Media tersebut harus mampu memberikan edukasi dan informasi tentang pencegahan komplikasi perdarahan dalam kehamilan (Darmawati, 2016) sehingga dapat meningkatkan pengetahuan masyarakat, khususnya ibu hamil tentang deteksi risiko perdarahan pada kehamilan. Media yang disediakan seharusnya mampu menyajikan materi khusus dan mampu membuat ibu hamil dapat belajar secara mandiri.

Salah satu yang dapat menunjang hal tersebut adalah media pembelajaran berupa modul. Modul merupakan media yang dapat membantu penerima informasi belajar secara mandiri dengan bantuan yang minimal dari penyuluh (Yaumi, 2018). Menurut Yuliana et al, (2012) bahwa modul merupakan salah satu media pembelajaran yang dirancang berbentuk media cetak dapat meningkatkan kemampuan peserta didik. Dengan demikian diharapkan pula dapat menjadi media pembelajaran untuk meningkatkan pengetahuan ibu hamil tentang deteksi risiko perdarahan pada kehamilan. Modul terbukti efektif sebagai alat bantu dalam penyampaian informasi kepada remaja dalam meningkatkan pengetahuan tentang kesehatan reproduksi (Johariyah dan Mariati, 2018).

Berdasarkan latar belakang di atas peneliti tertarik untuk menyajikan media edukasi deteksi risiko perdarahan pada kehamilan dalam bentuk modul yang dapat meningkatkan pengetahuan ibu hamil untuk melakukan deteksi risiko perdarahan pada kehamilan dan mampu mendeteksi dirinya jika mengalami faktor risiko perdarahan dalam kehamilan. Dengan demikian, Jika ibu hamil telah mengenali dirinya sebagai ibu hamil yang berisiko, maka komplikasi dapat dicegah dan segera mendapatkan pertolongan.

\section{METODE PENELITIAN}

Penelitian ini merupakan penelitian pengembangan yang mengadopsi tahapan dari model pengembangan dari Borg and Gall yang telah disederhanakan oleh Tim Pultijaknov (2008). Tahapan pengembangan modul terdiri dari analisis produk yang akan 
dikembangkan, pengembangan produk awal, validasi uji ahli, uji coba sampel kecil dan uji coba sampel besar. Lokasi penelitian untuk uji coba sampel besar atau pengujian efektifitas modul adalah di Wilayah Kerja Puskesmas Tajuncu Kecamatan Donri Donri Kabupaten Soppeng. Sampel dalam penelitian ini melibatkan 30 ibu hamil menggunakan teknik purposive sampling dengan kriteria sampel ibu hamil yang bisa membaca dan menulis.

\section{HASIL DAN PEMBAHASAN}

Pelaksanaan penelitian pengembangan ini dilaksanakan mulai bulan Oktober 2019 sampai Januari 2020. Tahapan penelitian pengembangan yang dilakukan oleh peneliti diuraikan sebagai berikut:

1. Melakukan Analisis Produk yang akan dikembangkan

Tahap awal pengembangan ini adalah dengan melakukan analisis kebutuhan melalui studi kepustakaan dan survey lapangan. Survey lapangan dilakukan melalui kegiatan Focus Group Discussion (FGD) dengan melibatkan dokter umum, bidan koordinator, bidan desa, petugas promosi kesehatan dan kader yang berada di wilayah kerja tempat penelitian.

Hasil dari kegiatan FGD tersebut didapati edukasi kepada ibu hamil mengenai deteksi risiko perdarahan pada kehamilan masih belum pernah dilakukan di wilayah kerja tempat penelitian. Kegiatan edukasi yang berlangsung selama ini baik kelas ibu hamil ataupun kegiatan diskusi faktor risiko dalam kehamilan menggunakan lembar timbal balik dan buku KIA sebagai media dalam penyampaian pesan. Sementara media yang membahas khusus tentang deteksi perdarahan pada kehamilan belum tersedia. Hal ini mengakibatkan pengetahuan ibu hamil tentang deteksi risiko perarahan masing kurang, dibuktikan dengan studi pengetahuan awal yang dilakukan peneliti mendapati hasil pengetahuan ibu hamil tentang perdarahan masih dalam kategori kurang.

2. Pengembangan Produk Awal Tahapan pengembangan ini merupakan pengembangan draft awal yang mencakup perumusan tujuan modul deteksi risiko perdarahan pada kehamilan dan menyusun bahan/ materi modul. 
3. Validasi Uji Ahli

Validasi uji ahli dilakukan untuk mengetahui kualitas dan kelayakan dari modul deteksi risiko perdarahan kehamilan yang dikembangkan. Pelaksanaan uji ahli dilakukan dengan menyerahkan draft awal modul untuk dinilai oleh masing-masing ahli berdasarkan instrumen validasi modul yang diterbitkan oleh BSNP (Badan Standar Nasional Pendidikan). Data yang disajikan dalam penelitian pengembangan modul deteksi risiko perdarahan pada kehamilan ini disajikan dalam bentuk data kuantitatif dan kualitatif.

Data kuantitatif yang disajikan dalam penelitian ini adalah hasil pengisian angket validasi para ahli media dan ahli materi terhadap modul deteksi risiko perdarahan pada kehamilan. Sedangkan penyajian data kualitatif merupakan masukan/ saran dari para ahli.
Berikut ini pelaksanaan dan penyajian data validasi uji ahli modul deteksi risiko perdarahan pada kehamilan:

a. Validasi oleh ahli media

Validasi produk dalam penelitian ini menggunakan dua orang ahli media yaitu Prof. Dr. Andi Alimuddin Unde, M.Si (ketua lembaga penelitian dan pengabdian kepada masyarakat Universitas Hasanuddin Makassar) sebagai ahli media I dan Prof. Dr. Ir. Hj. Sutinah Made M.Si (ketua pusat pengkajian dan pengembangan pembelajaran Universitas Hasanuddin Makassar) sebagai ahli media II.

1) Data kuantitatif

$$
\text { Berikut }
$$
adalah rekapitulasi hasil validasi ahli media terhadap modul deteksi risiko perdarahan pada kehamilan:

Tabel 1 Hasil Uji Ahli Media terhadap Modul Deteksi Risiko Perdarahan Pada Kehamilan

\begin{tabular}{|c|c|c|c|c|}
\hline & ASPEK PENILAIAN & AHLI I & AHLI II & $\begin{array}{l}\text { RATA-RATA } \\
\text { PENILAIAN }\end{array}$ \\
\hline & Ukuran Modul & 4 & 3 & 3,5 \\
\hline 1 & Kesesuain ukuran modul dengan standar ISO & 4 & 3 & \\
\hline 2 & Kesesuaian ukuran dengan materi isi modul & 4 & 3 & \\
\hline & Desain Sampul (Cover) & 3,87 & 2,87 & 3,37 \\
\hline 3 & Penampilan unsur tata letak & 4 & 3 & \\
\hline 4 & Warna unsur tata letak & 4 & 3 & \\
\hline 5 & Huruf yang digunakan menarik dan muda dibaca & 3,5 & 2,5 & \\
\hline 6 & Ilustrasi sampul modul & 4 & 3 & \\
\hline & Desain Isi Modul & 3,75 & 2,96 & 3,35 \\
\hline 7 & Konsistensi tata letak penampilan & 3,5 & 3 & \\
\hline
\end{tabular}




\begin{tabular}{|c|c|c|c|c|}
\hline & ASPEK PENILAIAN & AHLI I & AHLI II & $\begin{array}{l}\text { RATA-RATA } \\
\text { PENILAIAN }\end{array}$ \\
\hline 8 & Unsur tata letak bidang cetak dan spasi & 4 & 3 & \\
\hline 9 & Unsur tata letak judul dan ilustrasi & 4 & 3 & \\
\hline 10 & Tata letak penempatan & 4 & 3 & \\
\hline 11 & Tipografi isi modul sederhana & 3,25 & 2,75 & \\
\hline 12 & Tipografi isi modul memudahkan pemahaman & 3,5 & 3 & \\
\hline 13 & Ilustrasi isi & 4 & 3 & \\
\hline & Rata-rata & 3,87 & 2,94 & $\begin{array}{c}3,41 \\
\text { (Sangat baik) }\end{array}$ \\
\hline
\end{tabular}

Pada tabel di atas menunjukkan hasil validasi dua orang ahli media terhadap modul deteksi risiko perdarahan pada kehamilan diperoleh rata-rata 3,41. Hasil tersebut menyatakan bahwa modul yang dikembangkan dari segi media yang meliputi ukuran modul, desain sampul (cover) dan desain isi modul sangat baik.

Hasil penilaian masing-masing ahli dapat dilihat pada gambar grafik hasil uji penilaian ahli coba media berikut ini:

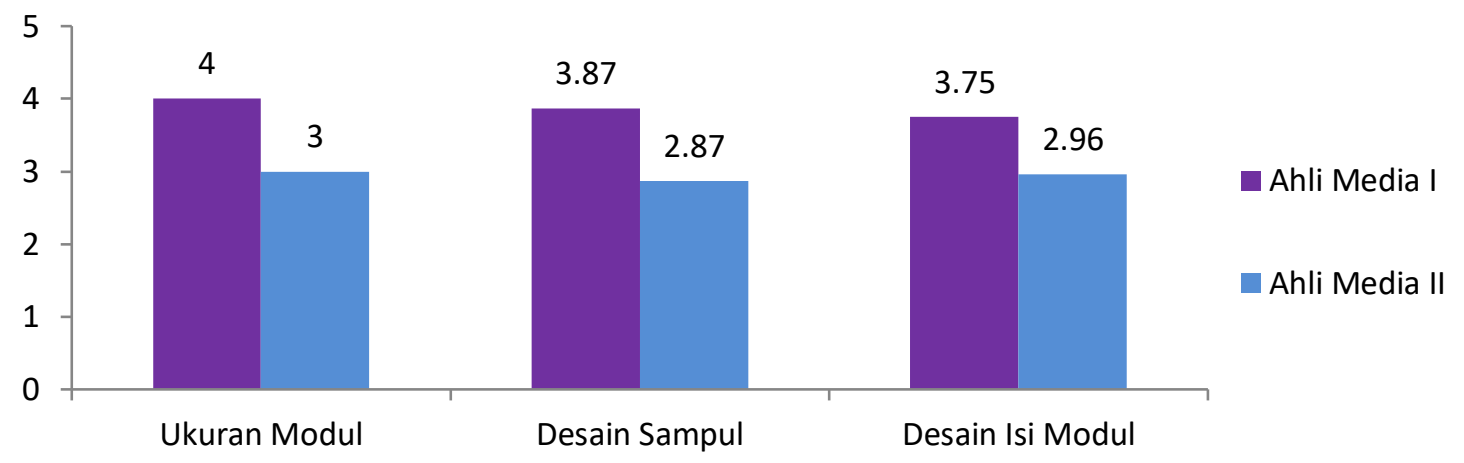

Grafik 1. Hasil Uji Ahli Media terhadap Modul Deteksi Risiko Perdarahan Pada Kehamilan

2) Data kualitatif ahli media

Data kualitatif yang

diperoleh dari masukan dan saran ahli media pada lembar angket adalah sebagai berikut:

Tabel 2 Masukan/ Saran Ahli Media untuk Modul Deteksi Risiko Perdarahan pada Kehamilan

\begin{tabular}{clc}
\hline No & \multicolumn{1}{c}{ Masukan/ Saran } & \multicolumn{1}{c}{ Keterangan } \\
\hline 1 & $\begin{array}{l}\text { Poin penting dalam setiap materi sebaiknya dilengkapi dengan } \\
\text { gambar yang relavans }\end{array}$ & Sudah direvisi \\
2 & $\begin{array}{l}\text { Sebaiknya tidak menggunakan banyak jenis huruf } \\
3\end{array}$ & $\begin{array}{l}\text { Lebih memperhatikan tata letak huruf, sebaiknya tulisan pada } \\
\text { setiap paragraf yang padat diberikan kotak }\end{array}$ \\
4 & Warna font dan background harus kontras & Sudah direvisi \\
& Sudah direvisi \\
\hline
\end{tabular}


Berikut tampilan modul deteksi risiko perdarahan pada kehamilan yang telah direvisi:

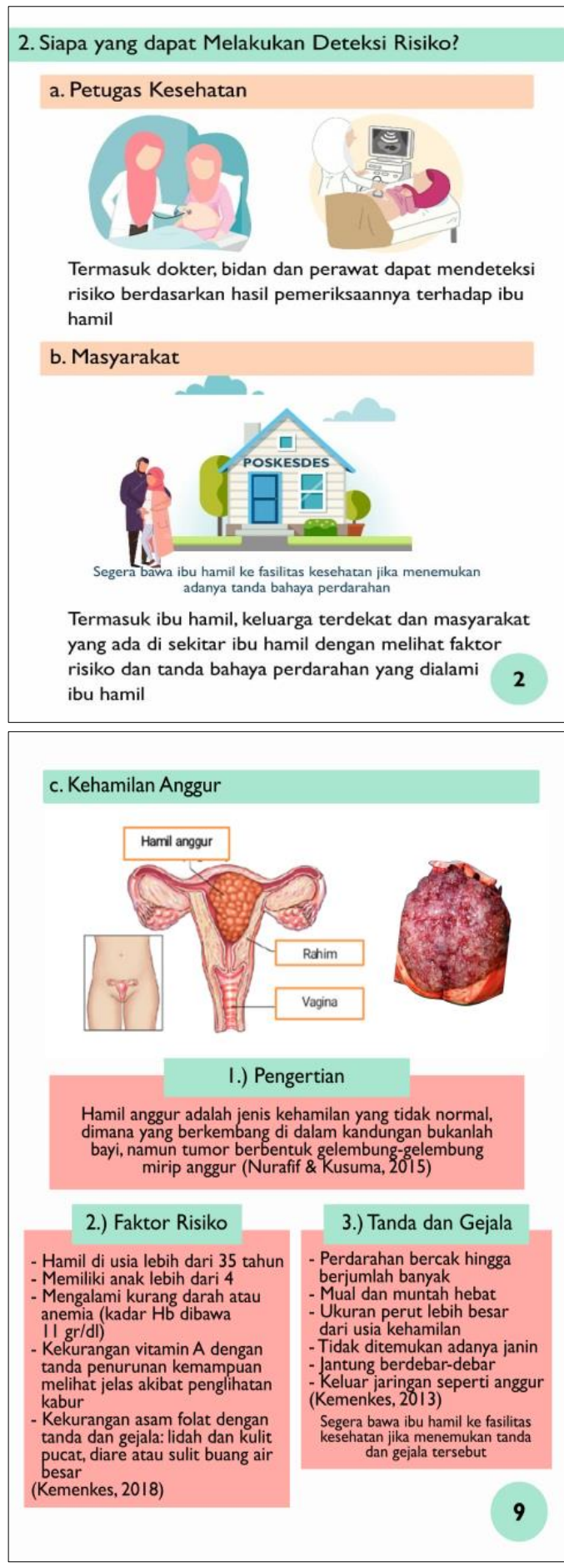

Gambar 1 Tampilan Hasil Revisi Modul Deteksi Risiko Perdarahan pada Kehamilan Sesuai Masukan/ Saran Ahli Media b. Validasi oleh ahli materi

Validasi ahli materi dalam penelitian ini adalah Dr. $\mathrm{Hj}$. Hasnah M.Noor, SKM, M.Kes (dosen jurusan Kebidanan Politeknik Kesehatan Kementerian Kesehatan Makassar) sebagai ahli materi I dan Dr. Theresia Limbong, SKM., M.Kes (dosen jurusan Kebidanan Politeknik Kesehatan Kementerian Kesehatan Makassar) sebagai ahli materi II.

1) Data kuantitatif ahli materi

Berikut adalah hasil validasi ahli materi terhadap modul deteksi risiko perdarahan pada kehamilan: 
Tabel 3 Hasil Uji Ahli Materi untuk Modul Deteksi Risiko Perdarahan pada Kehamilan

\begin{tabular}{|c|c|c|c|c|}
\hline & KOMPONEN & AHLI I & AHLI II & $\begin{array}{l}\text { RATA-RATA } \\
\text { PENILAIAN }\end{array}$ \\
\hline & Aspek Kelayakan Isi & 3,67 & 3,82 & 3,74 \\
\hline 1 & Kesesuain materi & 4 & 4 & \\
\hline 2 & Keakuratan materi & 3,8 & 3,8 & \\
\hline 3 & Kemuktahiran materi & 4 & 4 & \\
\hline \multirow[t]{2}{*}{4} & Mendorong keingintahuan & 4 & 3,5 & \\
\hline & Aspek Kelayakan Penyajian & 3,95 & 3,95 & 3,95 \\
\hline 1 & Teknik penyajian & 4 & 4 & \\
\hline 2 & Pendukung penyajian & 3,8 & 3,8 & \\
\hline 3 & Penyajian pembelajaran & 4 & 4 & \\
\hline \multirow[t]{2}{*}{4} & Koherensi dan keruntutan alur pikir & 4 & 4 & \\
\hline & Aspek Kelayakan Bahasa & 4 & 3,62 & 3,81 \\
\hline 1 & Lugas & 4 & 3,6 & \\
\hline 2 & Komunikatif & 4 & 3 & \\
\hline 3 & Diagnosis dan interaktif & 4 & 4 & \\
\hline 4 & Kesesuaian dengan perkembangan & 4 & 3,5 & \\
\hline \multirow[t]{2}{*}{5} & Kesesuaian dengan kaidah bahasa & 4 & 4 & \\
\hline & Aspek Kelayakan Konstektual & 3,9 & 3,75 & 3,82 \\
\hline 1 & Hakikat konstektual & 4 & 3,5 & \\
\hline \multirow[t]{2}{*}{2} & Komponen konstektual & 3,8 & 4 & \\
\hline & Rata-rata & 3,88 & 3,78 & $\begin{array}{c}3,83 \\
\text { (sangat baik) }\end{array}$ \\
\hline
\end{tabular}

Menurut hasil validasi modul deteksi risiko perdarahan pada kehamilan yang melibatkan dua ahli materi diperoleh rata-rata 3,83 . Hasil tersebut menyatakan bahwa modul yang dikembangkan dari segi materi yang meliputi aspek kelayakan bahasa dan kelayakan konstektual sangat baik.

Adapun hasil penilaian oleh dua orang ahli materi dapat dilihat pada gambar grafik hasil uji ahli materi sebagai berikut:

kelayakan isi, kelayakan penyajian,

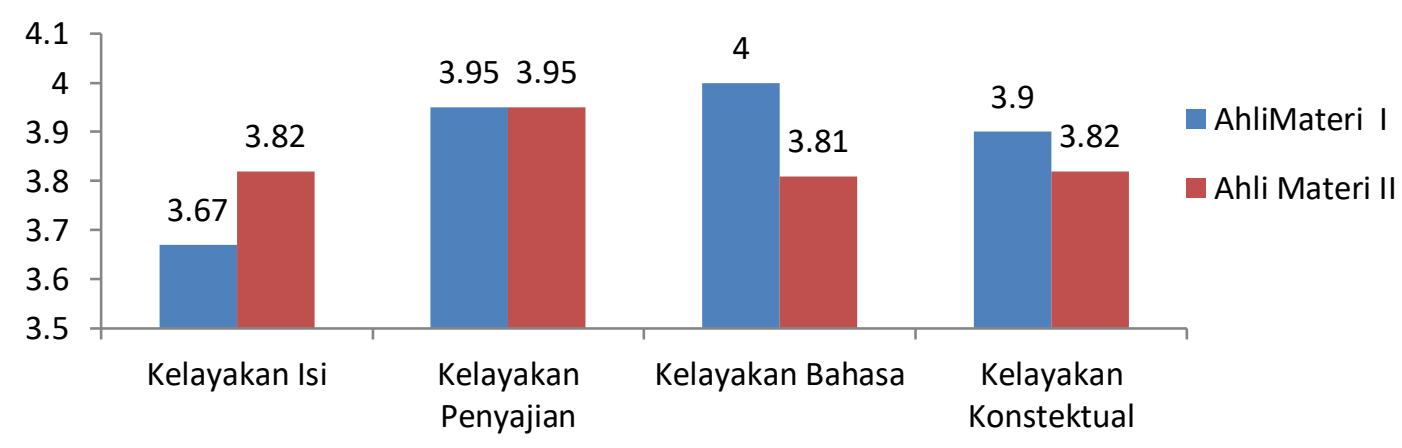




\section{Grafik 2. Hasil Uji Ahli Materi untuk Modul Deteksi Risiko Perdarahan pada Kehamilan}

2) Data kualitatif ahli materi

Data kualitatif
yang diperoleh dari
masukan dan saran ahli
materi pada lembar angket
adalah sebagai berikut:

Tabel 4. Masukan/ Saran Ahli Materi untuk Modul Deteksi Risiko Perdarahan pada Kehamilan

\begin{tabular}{|c|c|c|}
\hline No & Masukan/ Saran & Keterangan \\
\hline 1 & $\begin{array}{l}\text { Materi tentang ibu hamil } \\
\text { yang termasuk berisiko } \\
\text { perlu ditambahkan }\end{array}$ & $\begin{array}{c}\text { Sudah } \\
\text { direvisi }\end{array}$ \\
\hline 2 & $\begin{array}{l}\text { Faktor risiko ari-ari } \\
\text { menutupi jalan lahir perlu } \\
\text { ditambahkan }\end{array}$ & $\begin{array}{l}\text { Sudah } \\
\text { direvisi }\end{array}$ \\
\hline 3 & $\begin{array}{l}\text { Bahaya perdarahan pada } \\
\text { kehamilan dibedakan } \\
\text { antara perdarahan hamil } \\
\text { muda dan hamil tua }\end{array}$ & $\begin{array}{c}\text { Sudah } \\
\text { direvisi }\end{array}$ \\
\hline 4 & $\begin{array}{lr}\text { Kesimpulan sebaiknya } \\
\text { tidak terlalu banyak } \\
\text { (maksimal } 5 \text { poin) }\end{array}$ & $\begin{array}{c}\text { Sudah } \\
\text { direvisi }\end{array}$ \\
\hline
\end{tabular}

Tampilan modul yang telah direvisi:

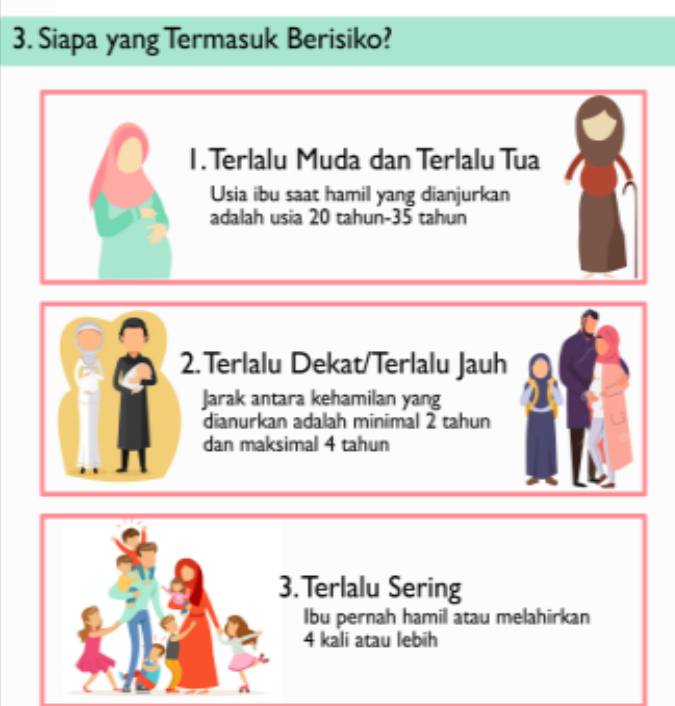

\begin{tabular}{|l|l|}
\hline $\begin{array}{l}\text { 4. Riwayat Kehamilan } \\
\text { dan Melahirkan } \\
\text { yang Buruk } \\
\text { bu pernah mengalami } \\
\text { perdarahan pada kehamilan } \\
\text { sebelumnya atau pernah } \\
\text { melahirkan dengan operasi }\end{array}$ & $\begin{array}{l}\text { 5. Riwayat Penyakit Ibu } \\
\text { lbu pernah atau sedang } \\
\text { mengalami penyakit tekanan } \\
\text { darah tinggi, jantung, anemia, } \\
\text { ginjal, penyakit gulakencing } \\
\text { manis dan penyakit kandung- } \\
\text { an seperti kista/tumor }\end{array}$ \\
\hline \multicolumn{2}{|c|}{} \\
(Kemenkes, 2018) \\
\hline
\end{tabular}

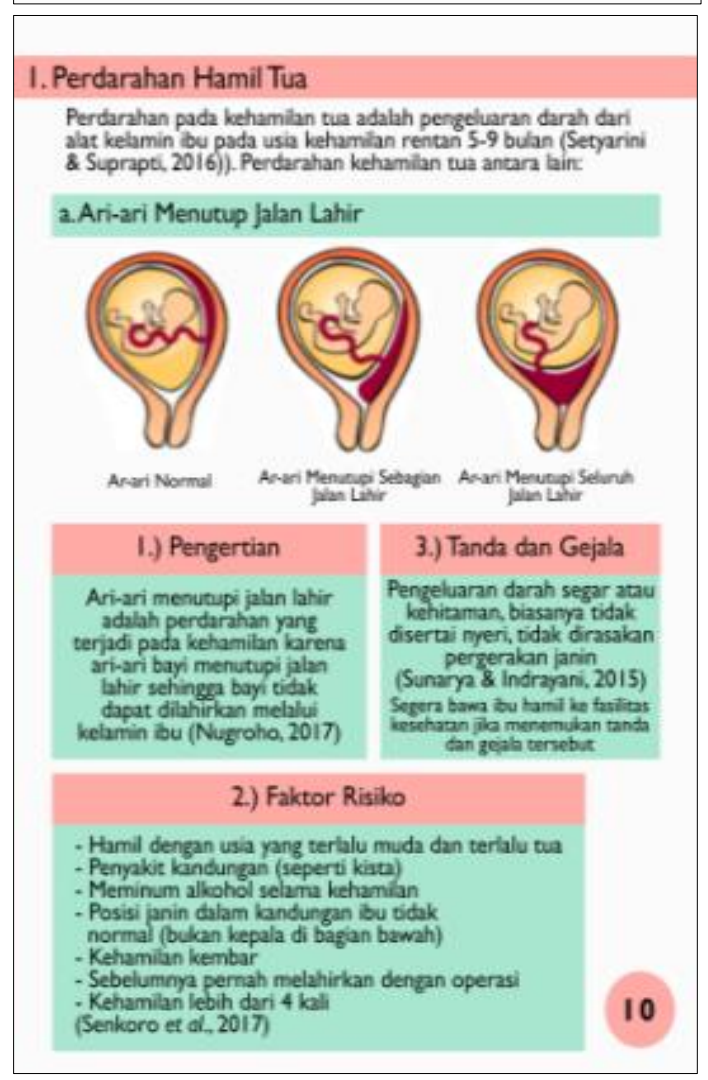




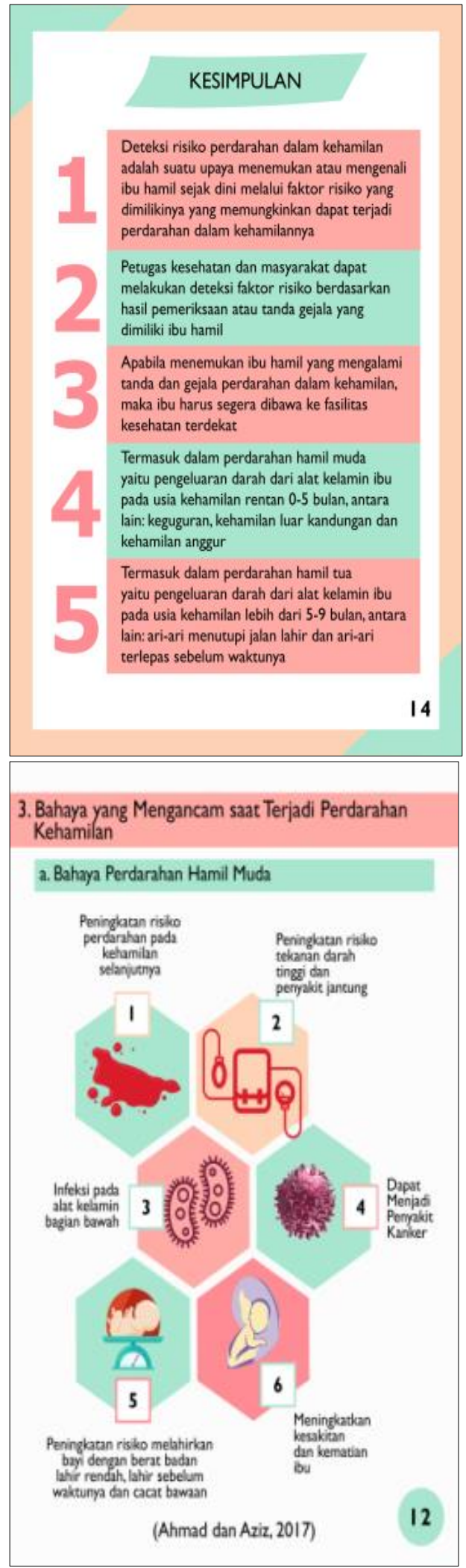

Gambar 2.Tampilan Hasil Revisi Modul Deteksi Risiko Perdarahan pada Kehamilan Sesuai Masukan/ Saran Ahli Materi

\section{Uji Coba Sampel Kecil}

Berdasarkan hasil uji/ telaah dari para ahli media dan materi, maka diperoleh beberapa masukan dan saran terhadap modul deteksi risiko perdarahan pada kehamilan. Kemudian modul direvisi/ diperbaiki berdasarkan saran dan masukan tersebut. Selanjutnya modul diuji cobakan pada uji coba sampel kecil yaitu melibatkan 10 ibu hamil sebagai pengguna modul. Adapun hasil penilaiannya adalah sebagai berikut:

Tabel 5. Hasil Uji Coba Sampel Kecil untuk Modul Deteksi Risiko Perdarahan pada Kehamilan

\begin{tabular}{cc}
\hline Komponen & Nilai Rata-Rata \\
\hline Ketertarikan & 3,73 \\
Materi & 3,73 \\
Bahasa & 3,73 \\
Rata-Rata & 3,73 (sangat baik)
\end{tabular}

Hasil uji coba modul diperoleh skor rata-rata keseluruhan yaitu 3,73. Hal tersebut menyatakan bahwa modul yang dikembangkan dari komponen ketertarikan, materi dan bahasa sangat baik. Lebih jelasnya dapat dilihat pada gambar grafik hasil uji coba sampel kecil sebagai berikut: 


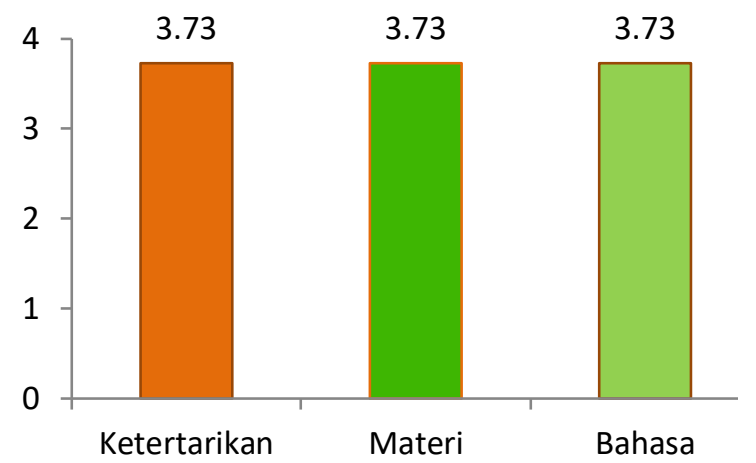

Grafik 3. Hasil Uji Coba Sampel Kecil untuk Modul Deteksi Risiko Perdarahan pada Kehamilan

\section{Uji Coba Sampel Besar}

Uji coba sampel besar merupakan tahapan penelitian untuk menguji efektifitas modul deteksi risiko perdarahan pada kehamilan terhadap pengetahuan ibu hamil. Pada tahapan ini dilakukan pengukuran pengetahuan ibu hamil sebelum dan setelah diberikan modul deteksi risiko perdarahan pada kehamilan. Adapun hasil pre test dan post test diperoleh hasil sebagai berikut:

Tabel 6. Hasil Uji Coba Sampel Besar untuk Modul Deteksi Risiko Perdarahan pada Kehamilan

\begin{tabular}{cc}
\hline Tahap & Nilai Rata-Rata \\
\hline Pre test & 60 \\
Post test & 85 \\
Peningkatan & 25 \\
Persentase Peningkatan & $41 \%$ \\
\hline
\end{tabular}

Hasil uji coba sampel besar menunjukkan nilai rata-rata hasil pre test $30 \mathrm{ibu}$ hamil sebesar $60 \%$ dan nilai rata-rata post test sebesar
85. Berdasarkan skor tersebut dapat dilihat peningkatan sebesar $41 \%$. Hal tersebut menyatakan bahwa modul yang dikembangkan efektif meningkatkan pengetahuan ibu hamil.

Selanjutnya dilakukan uji signifikansi perbedaan rata-rata skor pre test dan post test dengan menggunakan uji Wilcoxon dengan hasil sebagai berikut:

Tabel 7. Hasil Analisis Uji Wilcoxon untuk Modul Deteksi Risiko Perdarahan pada Kehamilan

\begin{tabular}{cccc}
\hline & Median & $\begin{array}{c}\text { Minimum }- \\
\text { Maksimum }\end{array}$ & $\begin{array}{c}\text { P- } \\
\text { Value }\end{array}$ \\
\hline $\begin{array}{c}\text { Pretest } \\
(n=30)\end{array}$ & 60 & $20-80$ & \\
$\begin{array}{c}\text { Posttest } \\
n=30)\end{array}$ & 86 & $66-100$ & 0,000 \\
\hline
\end{tabular}

Tabel 6 menunjukkan nilai median pretest sebesar 60 dari data tersebut dapat disimpulkan bahwa pengetahuan ibu hamil dinyatakan dalam kategori cukup, setelah diberikan intervensi berupa modul deteksi risiko perdarahan pada kehamilan pengetahuan ibu hamil mengalami peningkatan menjadi 86. Sementara itu hasil signifikansi $p$-value sebesar $0,000<$ 0,05 maka dapat disimpulkan modul deteksi risiko perdarahan pada kehamilan sifnifikan dalam meningkatkan pengetahuan ibu hamil. 
Penelitian ini menghasilkan sebuah produk modul deteksi risiko perdarahan pada kehamilan yang dapat dijadikan panduan oleh ibu hamil untuk menambah informasi tentang deteksi risiko perdarahan pada kehamilan. Komponen yang terdapat dalam produk modul yaitu redaksi modul, identitas ibu hamil, kata pengantar, daftar isi, pendahuluan, petunjuk penggunaan, tujuan, materi, kesimpulan, soal evaluasi, kunci jawaban, skrining/ceklist risiko perdarahan pada kehamilan muda dan tua, penutup dan daftar pustaka. Terdapat dua materi dalam modul ini, materi pertama membahas deteksi risiko pada kehamilan yaitu pengertian deteksi risiko pada kehamilan, siapa yang termasuk berisiko dan upaya apa yang dapat dilakukan untuk mendeteksi risiko kehamilan. Materi kedua memberikan penjelasan singkat kepada ibu hamil tentang pengertian, faktor risiko, tanda dan gejala serta dampak perdarahan pada kehamilan.

Materi yang disajikan dalam modul ini dapat membuat ibu hamil belajar secara mandiri karena di dalamnya terdapat soal evaluasi dan kunci jawaban serta di bagian penutup dilengkapi cara mengevaluasi hasil jawaban. Selain itu, modul juga dilengkapi skrining/ cekslist risiko perdarahan hamil muda dan hamil tua. Berdasarkan hasil pengembangan uji kelayakan produk yang melibatkan dua ahli media didapati modul deteksi risiko perdarahan pada kehamilan memperoleh nilai rata-rata 3,41 termasuk dalam kategori sangat baik berdasarkan komponen ukuran modul dengan hasil penilaian 3,5, desain sampul 3,37 dan desain isi modul 3,35. Hal tersebut sesuai dengan hasil penilaian ahli materi dengan rata-rata hasil penilaian 3,83 sehingga dikategorikan sangat baik dan tidak perlu dilakukan revisi. Hasil penilaian oleh dua orang ahli materi yang kompeten di bidangnya berdasarkan item-item yang terdapat dalam angket validasi meliputi aspek kelayakan isi sebesar 3,74, kelayakan penyajian 3,95 , kelayakan bahasa 3,81 dan kelayakan konstektual 3,82. Jadi berdasarkan uji kelayakan media dan bahwa modul deteksi risiko perdarahan pada kehamilan ini benar layak digunakan dan tidak perlu dilakukan revisi. Beberapa saran/ masukan dari para ahli media dan materi telah diperbaiki oleh peneliti sebelum diuji cobakan pada uji coba sampel besar.

Kelebihan yang dimiliki oleh modul ini adalah tampilan modul 
diberikan gambar/ ilustrasi yang menarik pada setiap poin penting pembahasannya yang didesain dengan tampilan yang menarik, colorful, sehingga dapat membantu memberikan penjelasan setiap isi materi sehingga tidak membuat bosan pembacanya. Selain itu isi materi yang terdapat dalam modul menggunakan bahasa yang komunikatif dan mudah dipahami oleh para ibu hamil terbukti dengan penilaian uji sampel kecil terhadap modul deteksi risiko perdarahan pada komponen ketertarikan, materi dan bahasa masingmasing 3,73 dalam kategori sangat baik. Sehingga modul tersebut dapat dikatakan layak digunakan dan tidak perlu dilakukan revisi.

Penelitian ini juga mendapati hasil bahwa modul deteksi risiko perdarahan pada kehamilan efektif dalam meningkatkan pengetahuan ibu hamil. Secara statistik (uji Wilcoxon) modul deteksi risiko perdarahan pada kehamilan signifikan dalam meningkatkan pengetahuan ibu hamil dengan $p$-value $0,000<0,05$. Sejalan dengan penelitian yang menjukkan ada perbedaan yang signifikan terhadap perubahan pengetahuan remaja sebelum dan setelah diberi pengetahuan kesehatan reproduksi dengan penyuluhan menggunakan modul KRR (Kesehatan Reproduksi Remaja) (Johariah dan Mariati, 2018) Implikasi dari peneltian ini adalah memudahkan dalam mempelajari materi perdarahan pada kehamilan dan terbukti dapat meningkatkan pengetahuan ibu hamil sehingga modul ini dinilai layak dan efektif dijadikan media edukasi.

\section{SIMPULAN DAN SARAN}

Berdasarkan hasil penelitian pengembangan diperoleh kesimpulan bahwa produk edukasi berupa modul deteksi risiko perdarahan pada kehamilan sudah sangat baik dan layak digunakan serta dinilai efektif mampu meningkatkan pengetahuan ibu hamil dengan presentase $41 \%$. Secara statistik (uji Wilcoxon) juga menyimpulkan bahwa modul deteksi risiko perdarahan pada kehamilan signifikan dalam meningkatkan pengetahuan ibu hamil dengan $p$-value $0,000<0.05$.

Penelitian pengembangan selanjutnya diharapkan dapat menambahkan materi tentang upaya pencegahan perdarahan pada kehamilan dalam modul deteksi risiko perdarahan pada kehamilan. Selain itu, pada komponen skrining/ ceklist risiko pada modul ini peneliti belum menguji 
efektifitasnya. Saran untuk penelitian selanjutnya diharapkan dapat melakukan pengujian efektifitas komponen skrining/ ceklist risiko untuk mendeteksi perdarahan pada kehamilan.

\section{DAFTAR PUSTAKA}

Achadi, E.L. (2019). Kematian Maternal dan Neonatal di Indonesia, Rakerkernas 2019, pp. $1-47$.

Anggraini, D., Abdollahian, M., Marion, K., Nuryani, S., Ramadhan, F., Rahayu, R.P., Rachman, I.R. and Wurianto, W. (2018). The Impact of Scientific and Technical Training on Improving Routine Collection of Antenatal Care Data for Maternal and Foetal Risk Assessment: A Case Study in the Province of South Kalimantan, Indonesia, Journal of Pregnancy, vol. 2018, pp. 113.

Darmawati, Octavia, S. A., Himayani, R., and Realita, F. A. W. D. B. W.. (2016). Mengenali Abortus dan Faktor yang berhubungan dengan Kejadian Abortus. Idea Nursing Journal, II(1), 75-80.

Dinas Kesehatan Kabupaten Soppeng. 2018. Laporan Ibu dan Keluarga Berencana. Dinas Kesehatan Kabupaten Soppeng. Soppeng.

Geller, S. E., Koch, A. R., Garland, C. E., Macdonald, E. J., Storey, F., Lawton, B., ... Belagavi, P. (2018). Sebuah pandangan global morbiditas maternal berat: bergerak di luar kematian ibu, 15 .
Johariyah, A. and Mariati, T. 2018, Efektivitas Penyuluhan Kesehatan Reproduksi Remaja Dengan Pemberian Modul Terhadap Perubahan Pengetahuan Remaja, Jurnal Manajemen Kesehatan Yayasan RS.Dr. Soetomo, vol. 4, no. 1, p. 38 .

Kementerian Kesehatan Republik Indonesia. (2016). Buku Kesehatan Ibu dan Anak. Jakarta: RI.

Kemenkes RI 2010, 'Pedoman Pemantauan Wilayah Setempat Kesehatan Ibu dan Anak (PWSKIA)', Kementrian Kesehatan RI, Direktorat Jendral Bina Kesehatan Masyarakat, Direktorat Bina Kesehatan Ibu, p. 1 of 76.

Kementerian Kesehatan, R.I. 2014, Pegangan Fasilitator Kelas Ibu Hamil, Pegangan Fasilitator Kelas Ibu Hamil, p. 102.

Sasnitiari, N. N., Supliyani, E., Rosaria, Y. W., Puspitasari, D. A., Studi, P., Bogor, K., ... Masyarakat, K. (2017). Hubungan Keikutsertaan Ibu dalam Kelas Ibu Hamil dengan Pengetahuan dan Sikap Terhadap Tanda Bahaya dalam Kehamilan di Kota Bogor. Jurnal Kesehatan Reproduksi, 8(2), 175-185.

https://doi.org/10.22435/kespro.v 8i2.6424.175-185.

Senkoro, E. E., Mwanamsangu, A. H., Chuwa, F. S., Msuya, S. E., Mnali, O. P., Brown, B. G., and Mahande, M. J. (2017). Frequency, Risk Factors, and 
Adverse Fetomaternal Outcomes of Placenta Previa in Northern Tanzania. Journal of Pregnancy, 2017 , $1-7$. https://doi.org/10.1155/2017/593 $\underline{6309}$.

Sindonews.com. 10 Oktober 2018. 11 Kabupaten di Sulsel Penyumbang Angka Kematian Ibu dan Bayi. https://makassar.sindonews.com/ read/15052/1/11-kabupaten-disulsel-penyumbang-angkakematian-ibu-dan-bayi1539105004.

Sikder, S., B, L. A., A, S. A., Hasmot, A., Sucheta, M., Lee, W., ... Parul, C. (2014). Risk factors for reported obstetric complications and near misses in rural northwest Bangladesh: analysis from a prospective cohort study.
BMC Pregnancy And Childbirth, 14 , 347. https://doi.org/10.1186/14712393-14-347

Widiastuti, T., Kartasurya, M. I., and Dharminto. (2014). Manajemen Deteksi Dini Ibu Hamil Risiko Tinggi pada Pelayanan Antenatal di Tingkat Puskesmas Kabupaten Jepara, 02(03), 261-267.

Yaumi, M. Media dan Teknologi Pembelajaran. (2018). Jakarta: Prenadamedia Group.

Yuliana, E., Sadjati, I.M. and Fadila, I. (2012). Penilaian tingkat Keterbacaan Materi Modul Melalui Evaluasi Formatif, Jurnal Pendidikan Terbuka dan Jarak Jauh, vol. 13, no. 2, pp. 113-24. 